\section{Rocky motoring}

Euan Nisbet

Understanding Earth. By Frank Press and Raymond Siever. W. H. Freeman: 1994. Pp. 593. \$44.95, £23.95 (pbk).

Exploring Earth and Life Through Time. By Steven M. Stanley. W. H. Freeman: 1993. Pp. 538. \$45.95, £22.95 (pbk).

A History of the Earth. By John J. W. Rogers. Cambridge University Press: 1994. Pp. 312. £50, $\$ 89.95$ (hbk); $\$ 39.95, £ 22.95$ (pbk)

A GOOD text can apologize for a hundred bad lectures: North America's generally excellent system of broadly based 100level university classes depends heavily on superb introductory texts that more than compensate for the drone of the minddead professor such as myself, plodding away while the hot-shots get on with their grant proposals. One of the curious rituals of spring in academia is the flight of the condors down the dusty corridors of the science departments, when powerful and elegant publishing creatures, wafting Chanel, turn their attentions to these tired professors. They swoop down, clutching the latest blockbuster text, and stun their victims into signing up for hundreds of copies. As the former teacher of a 'Rocks for Jocks' class of 400 nonscience students, including a good hunk of the football and ice-hockey teams, as well as teachers, nurses and nuns, I used to be prime meat for the sales reps. When one was spotted winging raptorially down the corridor, it was time to go into hiding for the morning, as I preferred to make my decisions in the quiet of a good bookshop. Despite the sales drives, for my firstyear nonscience students there were surprisingly few good choices of text, and in the end I wrote my own.

Two new books, 'downmarket'versions of well-known works by Frank Press and Raymond Siever and by Steven Stanley, should fill this important and neglected niche. The texts almost make it worth awaiting the circling reps, who will no doubt be hawking them about vigorously.

As expected from the record of the authors, these are fine books, well illustrated and thoroughly thought out. The books do not have the flair of a good single-author text, bubbling with ideas and interest. Instead, the authors and their production teams have opted for the detailed solid presentation and wellworked contents that will get the student from A to B no matter how badly the class is taught. The books are not Ferraris, but reliable, roomy and comfortable Chrysler minivans that can run safely on cruise control with only minor correction.

The texts differ strongly in emphasis. Press and Siever's work is strictly on

NATURE · VOL 370 • 28 JULY 1994 physical geology, a steady drive through the introductory chemistry, physics, tectonics, petrology and geomorphology of our planet. By contrast, Stanley takes a more biological route. Starting with a discussion of time and environment, he moves to the rock record and a brief excursion into tectonics, followed by a tour through the geological column, admiring its varied inhabitants from bacteria to dinosaurs. Both books are careful, clearly written and mostly reliable. I have my complaints, of course. The content of both books is distinctly elderly, reflecting the conventional wisdom of the $1970 \mathrm{~s}$, though to be fair there are frequent glimpses into modernity. The ageing is most serious in the discussion of subduction in Stanley's book, which is in need of major updating. Press and Siever also have their weaknesses, for instance in the treatment of the formation of oceanic crust at mid-ocean ridges. Given the importance of topics such as these, great care is needed in handling them, as it is often difficult to persuade students that a textbook is wrong.

Press and Siever's title, Understanding Earth (is it understanding? - I've thought of it as a tough old rogue, given to the shakes) is not to be confused with the excellent and newly reincarnated book Understanding the Earth edited by G. C. Brown, C. J. Hawkesworth and R. C. L. Wilson (Cambridge University Press, 1992), but the book by John Rogers might well be, as it does try to comprehend the planet. Rogers is a distinguished Earth scientist, and this book reflects an erudite and intelligent distillation of the contemporary view of our planet. Here is a book for advanced students that is fun to read, provokes thought, interest and annoyance, is not glossy (some of the diagrams are engagingly lousy) and has an integrity of argument and purpose that should make it perfect for reading in the washroom while one hides from the publishing representatives. The discussion is provocative and thoughtful, generally interesting, contemporary and reliable (though as a southern African whose family has for 150 years puzzled over the geological links between the Cape and the Falkland Islands, I must protest at the extreme political incorrectness of the "Malvino-kaffric" realm!). The bias is tectonic (unlike Preston Cloud's Oasis in Space (Norton, 1988) which is mainly biological), but there is also plenty of biology. It is well worth delving into, or raiding for lecture material. Although not a Ferrari, the book is perhaps best described as a Volkswagen with a V8 engine installed - powerful and enjoyable transportation for a higher-year core course.

Euan Nisbet teaches in the Department of Geology, Royal Holloway, University of London, Egham, Surrey TW2O OEX, UK.
Ancients and moderns

\author{
George C. McGavin
}

The Insects: An Outline of Entomology. By Penny J. Gullan and Peter S. Cranston. Chapman and Hall: 1994. Pp. 491. £24.99, \$39.95 (pbk).

Latin American Insects and Entomology. By Charles L. Hogue. University of California Press: 1993. Pp. 536. \$85, £60.

The Bee Genera of North and Central America. By Charles D. Michener, Ronald J. McGinley and Bryan N. Danforth. Smithsonian Institution Press: 1994. Pp. 209. \$53.95, £34.95.

Quaternary Insects and their Environments. By Scott A. Elias. Smithsonian Institution Press: 1994. Pp. 284. $\$ 47.95, £ 31.25$.

SINCE receiving The Insects I have referred to it daily, my other standby reference texts meriting only an occasional glance. It is an extremely well written and thoroughly up-to-date text, amply and clearly illustrated with magnificent black-and-white drawings. The authors have adopted a systems-based approach: there are large sections, for instance, on sensory systems and behaviour, aquatic insects, insects and plants, insect societies and pest management. Basic information about each insect order is provided in separate boxes, which are also used to deal with specific topics of interest such as figs and fig wasps, insect binary chemical weapons and biological clocks. Students wanting a single book to give them the whole picture need look no further. This work will appeal to those with only a passing interest in insects as well as rapidly become the standard teaching textbook on entomology.

From the crowded canopies of the rainforests and the vastness of the grasslands to the wilderness of the high Andes, there can be little doubt that South America is one of the most exciting parts of the world. Whether you are an armchair naturalist or a machete-wielding field biologist, you will find much that educates and enchants in Latin American Insects and Entomology. Despite the title, the text also covers selected terrestrial crustacean, arachnid and myriapod families.

The first fifth of the work is introductory, covering the history of Latin American entomology, general insect biology, South American ecology and economic entomology. The rest of the book reviews selected arthropod taxa (orders, families and some species), giving Spanish, Portuguese and English names, covers aspects of their biology and lists key references. It is hard to categorize this quirky but readable book. What the author has attempted and, to my mind, succeeded in doing is to 